\title{
Janina Labocha, Tekst, wypowiedź, dyskurs w procesie komunikacji językowej, Wydawnictwo Uniwersytetu Jagiellońskiego, Kraków 2008, ss. 207
}

Publikacja Janiny Labochy wpisuje się w nurt badań tekstologicznych. Traktuje o podstawowych terminach z zakresu teorii tekstu: tekście, wypowiedzi i dyskursie. Autorka, nawiązując do starszych i nowszych nurtów badawczych, uwzględniając bogaty dorobek szkoły tekstologicznej, pragmalinwistyki, a także teorii komunikacji, przybliża w książce własną koncepcję ujmowania trzech wskazanych pojęć. Akcentuje ten aspekt we Wstępie, formułując - w tym miejscu w sposób dość ogólny - cel pracy: „Celem niniejszego opracowania jest przedstawienie pewnej propozycji rozumienia tych terminów na tle wiedzy o języku jako podstawowym środku porozumiewania się międzyludzkiego" (s. 7). Szczegółowiej nazywa założenia pracy w dalszych jej częściach.

Zasadniczą kategorią opisu jest tekst ujęty jako spójna i utrwalona całość, mająca główny temat, zarysowaną perspektywę nadawczo-odbiorczą oraz funkcję komunikacyjną. Badaczka podkreśla: „Tekst jest rozumiany jako złożony znak, przeznaczony do jednostkowych, konkretnych aktualizacji. Prymarną aktualizacją tekstu jest odczytanie. Tekst zakłada również różnego rodzaju transformacje, w wyniku których na bazie tekstu prymarnego powstają różne jego przekształcenia (adaptacje, streszczenia, tłumaczenia, warianty redakcyjne itp.). Tekst jest jedynym w pełni dostępnym dla badań przedmiotem opisu. Jako obiekt badawczy podlega różnym metodom opisu” (s. 8-9).

Książka Labochy to praca przygotowana sumiennie i rzetelnie. Wypada w tym miejscu odnotować, że imponująco przedstawia się zakres wykorzystanej w niej literatury przedmiotu. Szczegółowy wykaz wszystkich publikacji czytelnik znajdzie w rozbudowanej Bibliografii, liczącej 362 pozycje. Zebrane opracowania autorka wyzyskuje w sposób umiejętny: chodzi jej o skomen- 
towanie, uzupełnienie i rozwinięcie swoich spostrzeżeń i postulatów. Warto również zaakcentować rozległość obszaru naukowych dociekań. Obejmuje on oprócz prac polskich - w tym licznych wcześniejszych publikacji Labochy dzieła czeskie, niemieckie, francuskie, anglojęzyczne.

Materiał badawczy, który posłużył autorce do sformułowania uogólnień teoretycznych, jest niejednolity. Tworzą go, bliskie Labosze, wypowiedzi z obszaru polsko-czeskiego pogranicza językowego na Śląsku Cieszyńskim. Są one dwojakiego rodzaju: $\mathrm{z}$ jednej strony wypowiedzi nagrywane $\mathrm{w}$ terenie, a następnie transkrybowane, $\mathrm{z}$ drugiej zaś - teksty pisane, pochodzące z zaolziańskiej prasy, książek i rozmaitych materiałów użytkowych z zakresu działalności kulturalnej, oświatowej czy politycznej. Badaczka wykorzystuje również materiały dydaktyczne zebrane podczas prowadzonych przez siebie zajęć językoznawczych. Jako bazę materiałową traktuje też wybrane prace licencjackie i magisterskie, poświęcone językowi mediów, nowym formom i technikom porozumiewania się, współczesnej literaturze pięknej i masowej.

Recenzowana publikacja składa się z trzech rozdziałów. Każdy z nich, $\mathrm{z}$ racji rozpatrywanego zagadnienia czy też sposobu opisu materiału, można by potraktować jako swoistą całostkę, odrębne studium o tekście. W rozdziale pierwszym, zatytułowanym Język, tekst, komunikacja międzyludzka, Labocha przybliża między innymi założenia teorii języka Karla Bühlera, wskazuje na podstawowe zagadnienia pragmalinwistyki i teorii komunikacji, omawia komunikację międzyludzką jako przedmiot analizy lingwistycznej. W centrum opisu umieszcza trzy terminy: tekst, wypowiedź i dyskurs. Badaczka nawiązuje do prekursorskich prac traktujących o tekście; wskazuje na ujęcia służące bliższemu określeniu zależności tekst - wypowiedź; odwołuje się również do nurtów uznających dyskurs za kategorię tekstologiczną.

Tym, co zasługuje na podkreślenie w koncepcji Labochy, jest obrona filologicznego statusu tekstu. Odwołując się do prac Anny Duszak ${ }^{1}$, w szczególności zaś do ustaleń Bożeny Witosz², badaczka twierdzi, że lingwistyka tekstu wypracowała całościową koncepcję tekstu, a wszelkie zmiany metodologiczne, zwłaszcza te dokonujące się pod wpływem intensywnego rozwoju teorii i analizy dyskursu oraz teorii kognitywizmu, nie przekreśliły dotychczasowych osiagnięć tekstologicznych. Podjęte rozważania, szczególnie wzbogacenie ich o perspektywę komunikacyjną, pozwalają autorce uznać tekst, wypowiedź i dyskurs za trzy różne zjawiska, wszystkie jednak kluczowe dla lingwistycznej teorii tekstu.

${ }^{1}$ Między innymi A. Duszak, Dokad zmierza tzw. lingwistyka tekstu?, Poznańskie Spotkania Językoznawcze, t. 9, Poznań 2002.

2 B. Witosz, Lingwistyka tekstu - stan aktualny i perspektywy, „Poradnik Językowy” 2007, z. 7 . 
Broniąc filologicznego statusu tekstu, Labocha przyjmuje, że tekst w przestrzeni komunikacyjnej funkcjonuje jako wypowiedź (określone zjawisko interakcyjne wbudowane w szeroko rozumianą sytuację komunikacyjną) lub jako dyskurs (typ kulturowy pewnego zbioru wypowiedzi, a także norma jej tworzenia w danym czasie i w danej wspólnocie dyskursywnej). Stąd też widzi konieczność uwzględnienia trzech różnych aspektów w opisie jednego, tego samego zjawiska językowego i kulturowego. Wyodrębnia tekst, wypowiedź i dyskurs. Tekst, czyli określony wytwór z przeznaczeniem do odczytania, streszczenia czy innej modyfikacji uznaje za jedyny dostępny i konkretny obiekt badań filologicznych. Wypowiedź postrzega jako zjawisko (zdarzenie) komunikacyjne, które ma charakter interakcyjny, ustaloną funkcję pragmatyczną i zarysowaną strategię nadawczo-odbiorczą. Z kolei dyskurs - regulator zachowań społecznych i językowych zbiorowości ludzkiej - traktuje jako normę możliwą do opisania na podstawie tekstów i wypowiedzi (zob. też s. 183-184).

Zdaniem Labochy tekst i wypowiedź, będące aktualizacjami (realizacjami) dyskursu, tworzą jego archiwum. Wskazując na takie archiwum, autorka w innym miejscu pracy - w Zakończeniu - formułuje postulaty badawcze. Za pilne zadanie współczesnej lingwistyki tekstu uznaje gromadzenie takich archiwów. Jako równie istotne i pożądane postrzega analizę i opracowanie tekstologiczne archiwum (m.in.: zróżnicowanych gatunkowo tekstów pisanych, tekstów zapisanych, nagranych wypowiedzi mówionych, rozmów internetowych).

W rozdziale drugim (Spójność tekstu i jego rozumienie) przedmiotem opisu czyni Labocha spójność, którą - nawiązując do założeń szkoły tekstologicznej Marii Renaty Mayenowej - rozpatruje przede wszystkim w aspekcie pragmatycznym. W Zakończeniu, zbierając wnioski, pisze: „Spójność tkwi częściowo w tekście, jednak dopiero aktualizacja tekstu w postaci wypowiedzi, będącej z kolei jedną z możliwych realizacji określonego dyskursu, stanowi o jego rozumieniu" (s. 183). Bazując na solidnych podstawach teoretycznych, autorka szczegółowo charakteryzuje metatekst. Przyjmuje bowiem, iż jest to kategoria służąca porządkowaniu przedstawianych zdarzeń, a ponadto element współpracy między narratorem a słuchaczem, ułatwiający spójny odbiór tekstu.

Niewątpliwy walor rozważań w tej części pracy stanowi materiał badawczy: teksty mówione w ,szacie pisanej”, tzw. teksty zapisane. Sa to teksty folklorystyczne (opowiadania ludowe, opowieści wierzeniowe, bajki) opublikowane w latach 1950-1984 w rubrykach Żywe teksty oraz Na tropach folkloru, przeznaczone dla czytelników znających gwarę cieszyńską. Analiza wskazanego materiału przynosi ciekawe i ważne spostrzeżenia.

Zwraca uwage przede wszystkim szerokie ujęcie metatekstu, który w wypadku tekstów zapisanych Labocha definiuje jako działania dwóch autorów 
na tekście właściwym. Dwaj autorzy to: nadawca wypowiedzi mówionej (gawędziarz) i twórca tekstu zredagowanego. Opis zjawisk metatekstowych obejmuje zatem dwie warstwy: implicytne i eksplicytne działania prymarnego nadawcy (gawędziarza) na tekście przedmiotowym oraz redakcyjne operacje metatekstowe.

O wartości analizowanego materiału przesądza również to, że dostarcza on uwag na temat rozmaitych mechanizmów i wykładników spójności. W pierwszej grupie zjawisk autorka rozpatruje między innymi komentarze wprowadzające, w których gawędziarz zapowiada temat, przekonuje o prawdziwości lub bajkowości opowiadanych zdarzeń, powołuje się na świadków wydarzeń lub jakieś inne źródło. Dokładnie omawia formuły rozpoczynające zredagowane bajki. Wiele uwagi poświęca tytułom; charakteryzuje je od strony zarówno funkcjonalnej, jak i strukturalnej. Opisuje również leksykalne elementy modalne - wykładniki modalności epistemicznej i sygnały czasowo-przestrzenne. Rozważania Labochy są szczególnie cenne: autorka dopełnia je licznymi odniesieniami do literatury przedmiotu, traktującej o rozmaitych środkach spójności w ogólnym rejestrze polszczyzny.

Redakcyjne operacje metatekstowe są o tyle znaczące, że aby wypowiedź tematyczna, mimo utrwalenia, mogła stać się tekstem, musi zostać poddana działaniom, które nadadzą jej szatę graficzną i wyposażą ją w sygnały ramowe początku i końca. Do tego typu operacji należą między innymi: ustalenie tekstu (wydzielenie z nagrania, a później z zapisu fragmentów tworzących wypowiedź tematyczną), ustalenie zawartości słowno-znaczeniowej zapisu (eliminacja wyrazistych zakłóceń toku mówienia, które w tekście pisanym utrudniałyby jego zrozumienie), wprowadzenie wtórnej segmentacji (np. leksykalnych wykładników segmentacji wypowiedzi mówionych), zastosowanie graficznych znaków interpunkcyjnych i dużych liter na początku wypowiedzeń, ułatwiających odbiór czytelniczy.

Rozdział trzeci (Struktura tekstu i wypowiedzi) traktuje o spójności w wymiarze tematycznym. Autorka sięga do koncepcji dotyczącej aktualnego rozczłonkowania zdania. Przywołuje między innymi ustalenia Teuna van Dijka w sprawie makrostruktury, czyli składnika w strukturze głębokiej (semantycznej), przesądzającego o tym, że zbiór wypowiedzeń to tekst. Zdaniem Labochy wniknięcie w strukturę globalną tekstu to czynnik zapewniający jego zrozumienie.

W omawianym rozdziale szczególnie wartościowe, teoretycznie i metodologicznie, są fragmenty mówiące o wykorzystaniu lingwistyki tekstu w dydaktyce. Dokładniej chodzi o kształcenie umiejętności tworzenia i wygłaszania wypowiedzi retorycznych. Labocha ujmuje taką wypowiedź jako ,indywidualne ustne zachowanie mowne w sytuacji publicznej (oficjalnej), którego podstawą 
jest wcześniej opracowany tekst, przeznaczony jednak nie do czytania, lecz do słuchania" (s. 161). Teksty przeznaczone do wygłoszenia, które są podstawą przemówienia i mają charakter tekstów wtórnie mówionych, obok zredagowanych tekstów gwarowych autorka uznaje również za teksty zapisane.

$\mathrm{Na}$ podkreślenie zasługuje koncepcja opisu wypowiedzi retorycznych polegająca na wydzieleniu składników struktury streszczenia tekstu zawartego w takich wypowiedziach. Labocha proponuje cztery składniki struktury streszczenia: tezę wypowiedzi wyrażoną zdaniem o określonej strukturze tematyczno-rematycznej, funkcję pragmatyczną wypowiedzi (sprecyzowaną moc illokucyjna, która sygnalizuje działanie komunikacyjne wypowiedzi), adres odbiorczy (zaprojektowanie odbiorcy przez nadawcę) i sytuację (zaprojektowanie siebie jako nadawcy ze względu na typ odbiorcy i parametry sytuacyjne). Zarysowana koncepcja pozwala na takie przygotowanie wypowiedzi retorycznej, które gwarantuje jej skuteczny odbiór.

Rozpatrując wypowiedzi retoryczne, Labocha postuluje również ich analizy składniowe. W badaniach składniowych, sprowadzających się do opisu spójności struktury powierzchniowej tekstu (kohezji), wskazuje na konieczność rozważenia nawiązań syntaktycznych oraz roli operatorów tekstowych. W dalszej części przedstawia, znaną ze swoich wcześniejszych prac, klasyfikację tych operatorów.

Zakończenie, zwięźle podsumowujące wcześniejsze ustalenia, autorka zamyka następująco: „Cały czas miałam na uwadze główną myśl, która przyświecała pisaniu tej pracy: tekst, wypowiedź i dyskurs to różne spojrzenia na to samo zjawisko, które można w pełni opisać jako twór, zdarzenie, normę, współtworzenie, interakcję, strukturę semantyczno-składniową i kompozycyjną itp., ale tylko wtedy, gdy wszystkie te pojęcia: tekst, wypowiedź, dyskurs w swojej różności a zarazem jedności zastosuje się w metodzie analizy, opisu i interpretacji tekstu w procesie komunikacji językowej” (s. 185).

Prezentowana książka jest publikacją ważną i wartościową. Oparta na solidnych podstawach teoretycznych i materiałowych nie tylko przybliża określoną koncepcję tekstologiczną. Porządkuje również dotychczasową wiedzę z zakresu lingwistyki tekstu, a ponadto wskazuje na dalsze obszary badań. 